DOI: https://doi.org/10.24297/ijmit.v16i.8941

\title{
Effect of economic sectors on employment in Sub-Saharan Africa.
}

Francis Kamau Ndung' ${ }^{1}$,

${ }^{1}$ School of Business, University of International Business and Economics (UIBE), Beijing, China.

\begin{abstract}
The motif of this study was to determine the effect of economic sectors on employment in Sub-Saharan Africa, given that the Sub-Saharan African region had had about two decades of sustained economic growth. Thirty Sub-Saharan African countries were used in this study, their data that was obtained and used spanning from the year 1990 to the year 2015. The study made use of the traditional neo-classical aggregate production function in the estimation of the regression results. The software program that was used in data analysis was STATA. Hausman test was undertaken and it determined that fixed effects estimations were preferred to random effect and as a result fixed effects were utilized in the study in carrying out regression analysis. On effect of economic sectors on employment, foreign direct investment was found to negatively influence employment though the influence was not statistically significant. The export and agriculture variables negatively and statistically significantly influenced employment. All the other variables in the study were found to positively and statistically significantly influence employment. Empirical results established that the gender gap in employment was maintained in the whole period of the study with more men being employed than women.
\end{abstract}

Key words: Sub-Saharan Africa (SSA), urban population, rural population, total population, economic sectors.

\subsection{INTRODUCTION}

\subsection{Background to the study}

Most Sub-Saharan African countries rely on exporting a few range of commodities a situation that makes them very vulnerable especially in the event of fluctuation of world prices as well as due to global economic shocks. As Sub-Saharan African countries have not been establishing many manufacturing entities, they as a result have not been able to create adequate jobs in the formal sector and due to this the population of these countries have not felt a positive impact of economic growth (The Economist, March 2014, McKinsey 2012).

AfDB, OECD, UNDP, UNECA (2014) in their report titled African Economic Outlook emphasized the need of structural transformation which was to start from natural resources sector. In 2011, Africa's export was $80 \%$ comprised of raw materials, and semi processed goods, which was much more compared to what other developing countries in other continents were exporting in terms of raw materials. Sub-Saharan African region should strive to diversify her economy given that the region has a comparative advantage based on natural resources. The Sub-Saharan African region was experiencing high poverty levels due to lack of adequate jobs for her unemployed population. The African countries ought to diversify their natural resources sector and in tandem diversify their manufacturing sector in order to create the needed jobs. The Sub-Saharan African countries ought to have adopted large scale farming so that they could enjoy economies of scale due to large scale production. Promotion of global value chain integration should as well be enhanced among the SubSaharan African nations. This was because Africa's share of global value chains was very low, only $2.2 \%$ by the year 2011.

\section{STATEMENT OF THE PROBLEM}

With reference to an outcome of a review of previous scholarly studies on effect of economic sectors on employment in Sub-Saharan Africa, there exists a dearth of studies that had been carried out on the contribution of economic sectors to employment, indicating the sectors of the economy with their specific contribution to employment, as well as contribution of total population and urban as well as rural population to employment in this region, the outcome of which could indicate which regions are endowed with establishment of more economic sectors, resulting in such regions contributing more to employment. This study was thus aimed at addressing that gap. 


\section{LITERATURE REVIEW}

\subsection{Factors supporting growth in Sub-Saharan African region}

Sub-Saharan African region realized impressive economic growth since the turn of the $21^{\text {st }}$ century, referred to as the new millennium, and this good economic performance of Sub-Saharan African countries resulted in creation of a lot of debate on its cause. There were both internal as well as external factors that fueled economic growth, but there is no consensus that had been reached on what the factors that propelled the Sub-Saharan African countries to achieve their current level of economic growth. Africa had benefited a lot from her favorable external context that had enabled her to export her products as well as attract capital. The bulk of the products that were exported by the Sub-Saharan African region, which constituted of fossil fuels, minerals as well as agriculture products had their prices rise considerably but in the year 2014, they started realizing a decline. SubSaharan African countries had as well realized growth due to having favorable internal factors that were good for her growth which included a favorable macro-economic climate, and its service sector was as well realizing rapid growth. The World Bank found that the Sub-Saharan African key economic drivers of growth included investment in public infrastructure, agriculture doing well due to more investment being made in the sector and favorable improved prices in the world market of agriculture products, as well as having a service sector that was thriving (World Bank 2014).

\subsubsection{Employment in SSA}

According to IMF (2012) and World Bank (2014) and (Filmer fox et al, 2013) in the current and future employment trends in SSA, the greatest number of people in SSA are still employed in the agricultural sector despite its contribution to GDP as at 2010 being only a paltry thirteen percent. This is in line with what Timmer (1988) postulated, that transformation of employment always lags the transformation of output. The demographic transition was lagging in Sub-Saharan African region and it was the main cause of the drag in general economic transformation including transforming the agricultural sector. This was happening despite the labour force being large and growing rapidly too, at a rate that was higher than in other middle income countries in Asia. The Agricultural sector had had a decline in its contribution to employment in the countries that were rich in natural resources as well as those that were deficient in natural resource endowment, both in low and middle income countries. However in resource rich countries the income derived from the sale of the natural resources had been used to create more jobs in the public sector (Fox et al 2013).

\subsubsection{Building the infrastructure and job creation in SSA}

Putting up good and proper infrastructure among the Sub-Saharan African countries was very crucial, as it would boost economic growth, create and sustain jobs as well as integrate trade and reduce poverty to great proportions. The Sub-Saharan African region needed to have an improved and efficient ICT infrastructure, set up a good road network, ports, railways, airports, pipelines and improve on energy production capacities. If proper transport infrastructure was set up in Sub-Saharan African region, costs of transport would reduce substantially especially transport of merchandise goods. The Sub-Saharan African region should establish an efficient and reliable electric supply network, which would boost the growth of economic activities as well as establish more industries that would create more jobs. South Africa, which was the most industrialized country in the Sub-Saharan African region, suffered from power outages making her economy suffer, due to reduction in production output which lead to reduction in profitability (AfDB, World Bank 2009).

$A f D B$, et al (2013) found that information and communication technology (ICT) enhancement resulted in improvements in infrastructure and creation of more jobs in the period 2000-2010. In this period SSA region realized better access to water and sanitation. However, electricity production stagnated and transport infrastructure development was limited in the period. North Africa and southern African regions were the most developed regions with reference to establishment of infrastructure in Africa and the other Sub-Saharan African region lagged behind this two regions basing on the infrastructure development index that was put forward by the African development bank (AfDB et al 2013).

The economist (2015) reported that Sub-Saharan African region was realizing major breakthroughs in infrastructure development as it had spent seven billion US dollars each year on paving roads. African transport infrastructure development had not been adequate as the paved roads in SSA were few, and rail development 
was inadequate. As a result of this the export costs of commodities from the Sub-Saharan African region became fundamentally high. Currently, tar mark and other paved roads connected Cairo, to Cape Town. Other infrastructure developments included the completion of construction of the Trans-Saharan high way connecting Algiers to Lagos. The Chinese had greatly contributed to the infrastructure development in the Sub-Saharan African region, for instance in construction of major rail network in Africa as well as its refurbishment. This is for instance the railway line connecting Angola, Zambia and the Democratic Republic of Congo. An electric railway line connecting Addis Ababa to Djibouti was as well constructed, its completion and commissioning happened in 2015 and the railway line infrastructure project to connect Kenya, Uganda, Tanzania, Rwanda, Burundi and South Sudan was being laid. These projects have resulted in creation of a lot of jobs directly and indirectly. The SSA is urbanizing fast, and thus there is need to extend their infrastructure as well as updating the existing one.

Deresa and Mbaku (2013) found that SSA region had a large potential of renewable energy, and if tapped, could enable this region to grow its industrial base. Despite this endowment, the SSA region still experienced an electric problem, for instance, power outages and rationing as it was heavily relying on hydroelectric power which was not very reliable during dry seasons. Renaissance Dam which was being constructed on Blue Nile was bound to be the largest in Africa. In the DRC, there was the construction of the Grand Inga Dam on river Congo which was bound to transform energy supply in this region. Construction of the dams for electric generation required a lot of funds which African countries did not have, which was the reason few such dams were constructed, and the Sub-Saharan African region lacked adequate electric power supply. The rivers in Africa had varied water volumes at different seasons of the year and this affected constant and adequate power supply in the Sub-Saharan African region. This lead to power rationing during dry seasons which translated to reducing employees in such seasons so as to break even.

Neslen (2015) studied various infrastructure projects that were taking shape in SSA. The study noted that in Rwanda at lake Kivu, Methane gas to electricity project was being implemented by a United States of American company which was being supported by US Aid, while the AfDB and the European Union and other donors were funding the lake Turkana wind project in Kenya that was to generate power using wind, Morocco on the other hand was reported to be building a solar mega project that is, a quartzite solar plant, which in its completion in 2020 would have enough power generating capacity to power one million homes. Many African countries are adopting a solar energy revolution especially at household level, as small solar panels were being availed at affordable prices to families and such families received small reimbursements later on.

\subsubsection{Trade and extractive industries in SSA.}

Export of commodities has been a great contributor to economic growth among SSA countries. Trade between African countries themselves been at an increasing trend, with the intra African exports constituting fifty percent of the total exports in the continent between the years 2010-2013. Most of this trade took place at intraregional level. Forty percent of the commodities that were manufactured in Africa were sold to other African countries and this was a clear pointer that African economies had started to diversify their production encouraging growth of import and export trade between the African countries. African countries formed regional trading blocs which greatly enabled intra-regional trade as this blocks lifted tariffs and other hindrances to regional economic integration, fuelling trade among the African countries (Zamfir 2016).

Africa has a huge land surface, and the natural resources are not spread in as large a proportion of the entire land surface as they are found in the OECD region, as in the OECD region most of the land surface and sub soil are covered by natural resources, and it is claimed that this could be the cause of lesser exploration of minerals in the African continent. The opinion of Africa having a reputation of being a resource - rich continent does not thus hold true. It was found that the natural resources that were found in the sub soil of the African continent amounted to only a fifth of the natural resources found in OECD countries. However, in the recent past, there has been successful exploration of oil and gas, as some new natural resources fields were discovered in the offshore of West Africa and in the East African region, ranging from Kenya to Mozambique (IMF 2013).

ACET (2014) in a study on African transformation reported that most of the African countries were heavily relying on exporting one or a few export commodities, and this resulted in exposing them to external shocks. It was reported that most of the natural resources rich countries had not diversified their economies and that there 
was linkage of the primary extractive sector to the rest of the economy, resulting in only few jobs being availed in the extractive sector. This has been the situation. For instance in the recent past Botswana struck diamonds, Guinea exploited bauxite, Niger mined Uranium, Ghana had been exploiting gold, while Nigeria had been mining oil. Some SSA countries had been exporting agricultural products for instance Kenya was the third largest exporter of tea in the world while India was the second and China was the leading tea exporter in globally. Ethiopia on the other hand was a major coffee producer. The problem with this agricultural products produced by African countries was that they were exported mostly in an unprocessed form.

\subsubsection{Agriculture and employment in SSA}

Balter and Harisen (2011) found that the agriculture sector in SSA countries was bedevilled by some impediments, which included issues such as land being either communally owned or owned by the government, which resulted in ownership rights that were not documented. It then made it impossible to acquire title deeds for ownership of such lands for use as collateral in obtaining loans that were vital in buying farm inputs for mechanising the production process of such lands so as to make the land more productive, and so as to reduce inefficiency in production. Governments in SSA ought to aid farmers by providing subsidies such as seeds and fertilizers. Some countries such as Ghana, Malawi, Tanzania and Zambia were able to provide their farmers with subsidized seeds and fertilizers, although such programmes had been criticized by being termed inefficient. Szirmai and Verspagen (2015) in a study found that the agricultural sector in SSA declined in terms of its contribution to GDP from $44 \%$ in the year 1950 to $26 \%$ in the year 2005 while on the other hand the industrial sector added more value to its output resulting in its increase to GDP in SSA from 19\% to 34 percent in the same period.

As result of having limited access to farm inputs and agricultural land, female farmers in SSA end up having lesser agricultural productivity in comparison to their male counterparts (Uduji et al 2019). This is in spite of the fact that agriculture remains the largest sector that employs most of the people in the region (FAO 2011). Though it has low productivity, it remains to be the greatest employer engaging 57 percent of the SSA employees, and it enables 90 percent of the inhabitants of rural areas in this region derive a livelihood (African development report, 2015). IFPR (2014) found that most of the poor people in SSA live in rural areas and their main source of livelihood is agriculture. Bayktar and Fofack (2018); Elu, (2018); Mannah - Blankson, (2018); Manyire and Apekey, (2013); Uduji,et al (2018a) found that more resources in the agricultural sector such as land and farm inputs were allocated to men, though agriculture in this region was affected by low level of mechanization and this hampered productivity in this sector.

\subsubsection{Building the infrastructure and job creation in SSA}

Putting up good and proper infrastructure among SSA countries is very crucial, as it will boost economic growth, create and sustain jobs as well as integration of trade and reduce poverty to great proportions. The SSA region needs to have an improved and efficient ICT infrastructure, set up a good road network, ports, railways, airports, pipelines and improve on energy production capacities. If proper transport infrastructure is set up in SSA region, costs of transport will reduce substantially especially transport of merchandise goods. The SSA region should as well establish an efficient and reliable electric supply network, and this will result in growth of economic activities as well as establishing more industries which result in creation of more jobs. South Africa, which is the most industrialized country in SSA region, suffers from power outages making her economy suffer, due to reduction in production output which as well leads to reduction in profitability (AfDB, World Bank 2009).

Ey (2014) found that many SSA countries had put up many infrastructural projects as for instance in 2012 the European Union noted that there were eight hundred infrastructural projects that that were being constructed, and Nigeria as well as South Africa were the two countries that were having the lion's share of majority of the infrastructural projects that were underway. Putting up necessary infrastructure contributed heavily to economic growth of countries and regions and this is due to job creation that ensues and, it stimulates increased demand for building materials and needed equipment's. The maintenance that happens after the construction of the infrastructural projects continues supporting the economy of a country and this translates to growth of SSA region. Putting up infrastructural projects acts as a catalyst of economic growth as it activates a lot of investment projects. China had a model of building up infrastructure, setting to act as a driver of economic growth, and 
some other SSA countries have followed this model, an example being Ethiopia, which happens to be one of Africa's fastest growing economies. However this model has a problem as it sets up a strong recession if financial resources dry up. For the SSA countries to undertake adequate economic diversification and pursue structural transformation, they must improve their infrastructure, so as to transform their economies through for instance, improving on their energy supply.

AfDB (2013) found that information and communication technology (ICT) enhancement resulted in improvements in infrastructure and creation of more jobs in the period 2000-2010. In this period SSA region realized better access to water and sanitation. However, electricity production stagnated and transport infrastructure development was as well limited in the period. North Africa and southern African regions were the most developed regions with reference to establishment of infrastructure in Africa and the other SSA region lag behind this two regions basing on the infrastructure development index that was put forward by the African development bank (AfDB2013).

\subsubsection{Services sector and employment in SSA}

In most African economies, the services sector has experienced tremendous growth. Between the years $1995-$ 2011, the services sector had the highest growth and as a result two thirds of the GDP in SSA countries was derived from the services sector. The major sectors that contributed to this hefty growth in the GDP included telecommunication, financial services and tourism. Agriculture and manufacturing industries have been outpaced in the past two decades by the services sector making it the main contributor of growth in the SSA countries economy. There are some SSA countries that have greatly benefitted by the contribution of the services sector to their GDP and in employment generation. They include Nigeria, Tanzania, and Uganda (Accenture 2014). The SSA region has reaped a lot of revenue from telecommunication infrastructure sector. A lot of jobs have as well been created in this sector. The SSA region had not been well connected by landlines, and since the year 2000, with the introduction of mobile phones in this region, their use spread very fast in the whole region. Internet use has as well spread rapidly, and this has been supported by the users of mobile data. The rural areas communication network has thus been opened up, and this has linked up these areas to modern economic processes. The rapid penetration of ICT has had great contribution to other economic sectors, as it improved communication which enabled the business to transact, and people to communicate easily in passing of important information to each other in a fast, efficient and cost effective manner (Accenture 2014).

\subsubsection{The Manufacturing sector in SSA}

Earlier studies had established that the manufacturing sector was the key ingredient to economic growth among countries, but, this currently is not the case, as many countries are realizing that the services sector is doing much better in terms of deriving higher income that results in much greater economic growth surpassing the industrial sector as it is now the case in SSA region. The nortion of the manufacturing sector being the keg that grew the world economies fastest has been challenged as the services sector has been reported in recent studies to be doing much better (Szirmai and Verspagen 2015).

The services sector performs even much better in comparison to the manufacturing sector in the developed world as its output surpasses two thirds of the national output, which puts the services sector ahead of the manufacturing sector in the generation of national income. This situation has as well been similarly reported among the developing countries. The services sectors comprising of software, business processing, finance and even tourism sectors has generated much more revenue in total in comparison to the manufacturing sector which has been reported in various countries for instance in India (Dosgupta and Sing 2005). This however cannot discount the importance that industrialization has played in growing economies for instance among the East Asian economies which grew as a result of industrializing in the past fifty years and, the world history in terms of economic development since the year 1870 has registered manufacturing as pivotal in the countries development (Szirmai 2012). The manufacturing sector accounts for an average of an average of $11 \%$ of the gross domestic product in Africa, which is a small contribution. Africa is focusing on the manufacturing sectors that have a higher potential for growth such as agro processing and value added services. The African continent had its industrial sector increasing from $19 \%$ to $34 \%$ between the years 1950 to the year 2005. In a study that was conducted by Szirmai and Verspagen (2015) on the impact of the manufacturing sector to economic growth 
in Africa between 1950 and 2005, it was found that the manufacturing sector had a moderate positive impact on economic growth in Africa. The manufacturing sector has been found to have a declining contribution to economic growth in the SSA region from the 1990s.

Wonyra (2018) found that value added manufacturing sector had a positive impact on economic growth among the SSA countries. It was also found that human capital accelerated the contribution of manufacturing to economic growth. It was thus established that it was important to invest in human capital so as to enable the SSA countries to realize their structural transformation much more easily, as it was established that the transition to the manufacturing sector had a positive interaction with economic growth.

Kaldo (1966) and Rodrick (2009) found that the manufacturing sector acted as the engine of economic growth, as they found a correlation between the degree in which countries were industrializing and their level of economic growth. Those developing countries that had higher levels of per capita income had set up a considerable number of manufacturing industries which resulted in the manufacturing sector contributing a considerable portion of income in their GDP, and which resulted in an increase in the level of employment. This resulted in such countries generating quiet a large proportion of their manufacturing output that increased their exports. Rodrik (2009) argued that those countries that had not industrialized became poor, and they relied on their Agricultural sector in contributing to their economic growth and its contribution to GDP was low.

\subsubsection{Foreign direct investment (FDI)}

The European Union (2014) did a study it named as attractiveness survey and found that the second most attractive destination for FDI world over in the year 2014 was Africa, though there are still some negative sentiments on issues of investing in Africa which limit the flows of FDI into the African continent. Foreign investors have had a considerable interest in investing in Africa not only in government bonds but as well investing in private sector. Africa only gets a meager share of $5 \%$ of the total worth of FDI, despite attracting increased flows on FDI. The investment between the North African region and the entire SSA region differs. There is a decline on FDI in the North Africa, while the SSA region is still realizing a net growth on FDI, which increased at the rate of $4.7 \%$ in the year 2014. The countries that attract increased FDI flows include the ones referred to as regional hubs which constitutes of South Africa, Nigeria and Kenya, while the emerging economies that as well attract foreign direct investment include Ghana, Mozambique, Zambia, Tanzania and Uganda.

The slowing down in the Chinese economy as well as changing economic situation in the world has resulted in significant effects in investment in Africa. This is because China has invested heavily in the African continent, both in infrastructure projects as well as in extractive industries Financial Times (2015).

Ndabendia and Njoupougnigni (2010) in a study establishing the relationship between economic growth, foreign direct investment and foreign aid found that foreign aid and foreign direct investment had a positive impact on economic growth. It was established however that foreign Aid had lesser effect on economic growth in Sub-Saharan Africa. Other studies such as those of Khawar (2005), Roy and Berg (2006), Xu and Wang (2007), Bhandari et al (2007) and Liu (2005) established a positive and statistically significant effect between foreign direct investment and economic growth. Adams (2008) however found that the effect of foreign direct investment on economic growth was precipitated by some other institutional factors such as employee's educational level, required physical and other basic infrastructure in organizations, and how appropriate the institutions were so as to harness economic growth given the amount of foreign direct investment that had been injected. For a country to attract foreign direct investment and realize economic growth though such a country needed to meet some other conditions that are deemed to be necessary though not sufficient such as having in place policies that are deemed to be good, political as well as economic stability. It was however established that domestic investment had more significance in accelerating economic growth.

\subsection{Labour migration across sectors and increase in productivity.}

Rodrik (2014) found that though there was no evidence that structural transformation had been achieved in SSA countries, but it was factual that there had been labour migration from agriculture to other economic sectors, but again there was no proof if this had led to increase in productivity levels. There had been rural urban migration in SSA countries, with workers or job seekers migrating from traditional agricultural sectors in the 
rural areas to the cities where they get engaged in sectors engaging in services. Latin America as well as East Asian countries have however in sharp contrast managed to migrate their workers from agriculture to high productivity sectors - manufacturing and modern sectors of their economy resulting in achieving structural transformation.

Bidiane et al (2012) observed that though SSA countries have been independent in the past five decades they've not been able to achieve structural transformation, instead, they have ended up achieving negative structural change that has led to low productivity, and this has been as a result of labour migrating from agriculture sector that has been underperforming but which has much higher productivity into an oversized lower productivity service sector. They observed that productivity in the agricultural sector had remained stagnant since 1980 and that there had been a decline in sectors of the economy which later stagnated.

\subsection{Previous empirical studies on gender, employment and economic growth}

Wonyra (2018) found that the manufacturing sector has great capability of enabling capital generation and accumulation than the agricultural sector, as its per unit output is higher due to higher labour productivity as well as increased factor productivity, which is higher in the manufacturing sector than in other sectors. This is what enabled East Asian countries to develop as it boosted their savings which these countries ploughed back to invest further in more manufacturing firms. Capital accumulation is thus one of the sources of economic growth. It thus translates to the fact that a growing manufacturing sector leads to overall growth of the economy. It means that the manufacturing sector has a higher capital intensity than in other sectors but according to Szimazai (2012), this is found occurring among the developing countries but not among the developed countries.

Fei and Ranis (1964) found that the manufacturing sector had a greater productivity level than the Agricultural sector, which according to them was supposed to have higher productivity than all the other sectors, thus, while undertaking economic transformation, resources should be reallocated from the less productive sectors such as Agriculture to the more productive sectors such as the manufacturing and services sectors. Inklaar et al (2008) were of the opinion that more resources should be allocated to the most productive sectors irrespective of whether it was the Agricultural sector, the services sector or the manufacturing sector.

Dieterich et al (2016) found that though urbanization provides better job prospects away from the Agricultural sector, it however ends up having more men gainfully employed than women. In comparing the level of gender disparity in employment between rural and urban areas, it was found that in the rural areas, the gender disparity was much narrower in the employment sector than in urban areas due to there being more wage sector jobs in urban areas than in rural areas. For instance it was established in the study that Burkina Faso with an urban population to total population ratio of $29 \%$ in the year 2014 had fewer jobs in rural areas with employment sector job distribution being similar between the sexes. In spite of this, in the urban setting, there were $10 \%$ more males in gainful employment than females. On the other hand, Rwanda with a share of urban population of $28 \%$ had its rural population having males being more in gainful employment, though the gender gap was narrower in the rural areas while in the urban areas, the males who got wage employment comprised of a proportion of $55 \%$ while the female's proportion was a paltry $21 \%$ in the same country. Ghana, on the other hand with $53 \%$ of its population living in the urban areas had more of its females working in the household enterprise sectors. In contrast, the males had more than twice the chance of getting wage employment in urban areas than in rural areas. Zambia though had a lower proportion of its population living in urban areas than Ghana, had $40 \%$ of its population living in urban areas, and had a similar pattern of employment to that of Ghana.

It was found that after getting married many women dropped out of employment with their positions being taken over by men, with the proportion of unemployed married men being quite small in comparison to all other groups in the SSA labour force. $63 \%$ of females stated domestic responsibility as the reason of them dropping out of formal employment, a reason which none of their male counterparts gave as reason of leaving formal employment, (Dieterich et al 2016). 


\subsection{Effect of Corona virus (Covid - 19) pandemic on employment and economic growth in SSA.}

Both the export and import of food commodities were found to have had an average rise by $18 \%$ and $25 \%$ respectively. The reason as to why there was an increase in exports was due to increase in exportation of food commodities as Kenya exported food commodities to especially her neighboring trading partners. There was a decline in importation of durable luxurious commodities and this was replaced by more food commodities as well as medicine and personal protective equipment for treating covid-19 pandemic being sourced through importation. The study established that there was inadequate evidence that the lockdown policies that had been effected disrupted trade on medical supplies for treatment of the corona virus disease (Socrates 2020).

There was near total disruption in sea transport which negatively impacted import of commodities in Kenya due to the lockdown guidelines that had been implemented, but this was compensated by a rise in air cargo transport as air cargo transport had become relatively cheaper as more air ways resorted to air cargo transport as passenger air transportation had been hampered by the covid-19 pandemic. The study found that those countries that had strict policies on public health had decreased commodities exported to them, but imports from such countries had a significant increase. Exports to OECD countries were not affected, but on the other hand, imports from this countries increased significantly. It was established that Kenya's trade with China had a significant decline when China effected lockdown measures (Socrates 2020).

Tourism contributed about 13 percent of the gross domestic product (GDP) in the Sub-Saharan African region. This sector had however been adversely affected due to cancellation of hotel bookings and suspension of flights. This region lost approximately US Dollars 8.8 billion monthly as tourism contributed about 6 percent to the SubSaharan African region's gross domestic product (African travel and tourism Association 2018).

With the suspension of production in both formal and informal sectors, production was adversely affected. This resulted in reduction in both government's revenue as well as government's expenditure in the region, and the cost of doing business was bound to increase further, and the liquidity was tightened. With the reduction in supply of essential commodities among some Sub-Saharan African countries, prices of such commodities had markedly increased. Many companies closed down, and the few that continued with their production process, their operational costs rose as a result of restriction in the supply of the inputs. This has resulted in some job losses as regional stores closed down due to incurring losses. Some companies realized losses while others realized reduced profits (Lusaka times 2020).

The informal sector in Sub-Saharan African region which accounted for up to 76 percent of the employment had suffered greatly. This sector was comprised majorly of business people that run their enterprises as sole proprietors, some of who were street venders. They had realized great losses due to restriction in movement social distancing requirements and lockdowns as covid-19 containment measures. There had been reduction in liquidity due to the containment measures, these businesses had not been able to buy adequate stock that would last their businesses the whole period of lockdown (Ndiili 2020).

The Sub-Saharan African governments came up with measures to save the businesses, for instance exempting those businesses from paying taxes, and availing loans and grants to varied businesses. Some countries in SubSaharan Africa such as Zimbabwe and Rwanda provided relief packages during the covid-19 pandemic to vulnerable families (Zambia observer 2020).

\subsection{Transformation of the SSA region economy}

Lin (2012) observed that Sub-Saharan Africa was suffering from de-industrialization, just like other regions in the world. The reduction in the number of industries in operation in Sub-Saharan Africa resulted in reduction in number of people working in the industries. The reduction in the number of industries was occasioned by closure of some industries due to them shutting down for varied reasons. De-industrialization could as well occur due to increase in the population at a rate that couldn't be absorbed to work in the existing manufacturing industries, and they ended up working in other sectors of the economy such as in the services sector, as this sector had been growing in all regions of the world. De-industrialization was a phenomenon that had been observed in all regions of the world, from USA, Europe, East Asia as well as Latin America. This was a trend that was greatly worrying in Africa, as Africa could not have been able to shift her population working in the farms 
to enlisting them to work in the factories, if it could manage to set up more industries than the ones that the Sub-Saharan African region already had as they were inadequate. The contribution of jobs in the manufacturing sector constituted only $6 \%$ of all jobs in the Sub-Saharan African region and this percentage had remained static for three decades. Some countries in Sub-Saharan Africa however had superseded this, for instance Ethiopia had managed to grow her manufacturing sector at an average that was over $10 \%$ per annum, for instance this was achieved between the years 2006-2014, though she started establishing her industries from a very low base. In the same vain, Tanzania had as well managed to grow her manufacturing sector output by $7.7 \%$ each year from 1997 to 2012.

\subsection{Variation of economic transformation among the SSA countries}

(UNECA 2014) found that strong differences existed between countries and regions on the basis of economic transformation. Southern Africa and northern African regions had realized the most rapid economic transformation, with their share of agriculture in GDP having declined in the fastest rate. Oil importing countries had a lesser industrial share in their GDP than their oil exporting countries counterparts. This was basically due to the economic weight that had been placed on the extractive industries among the oil exporting countries. Mc Kinsey (2010) in a report supported this argument, pointing out that some countries in the Sub-Saharan African region had diversified their economies. The report pointed out that the least diversified countries in Africa were the oil exporting countries.

ACET (2014) found that some Sub-Saharan African countries had come up with more sophisticated and export oriented production. They had done this both in their agricultural production as well as in the industrial sector, though such industries were not many in number. This had for instance been implemented in the cut-flower production in East Africa, and there was what was referred to as back office services as well as garments industries in Madagascar and Lesotho. (Page 2012) found that Mauritius had achieved the status of being the most successful in economic transformation in Africa. Mauritius was for instance able to develop a highly competitive international garment manufacturing sector, as well as tourism service sector, raising its GDP per capita to significant proportions that are above the African average.

\subsection{METHODOLOGY}

\subsection{Data that was used in the study}

This study undertook an empirical study on 30 Sub Saharan Africa countries spanning the period 1990 to 2015 with the data having been obtained from the data banks of the World Bank and World development indicators as well as from FAOSTAT. The study used the traditional neo-classical aggregate production function in the estimation of the regression results in order to determine the effect of the respective variables on employment levels in SSA by using employment levels as the dependent variable.

\subsection{Theoretical Models}

The theoretical model that was used to find out the interrelationship between economic sectors and employment was based on the traditional neo-classical aggregate production function of the following nature:

$Y_{j t}=A K_{j t}^{\alpha} L_{j t}^{1-\alpha}$

Where:

$Y=$ gross domestic product (GDP) in country $j$ and year $t$

$\mathrm{K}=$ capital stock (domestic capital investment) in country $j$ and year $t$

$\mathrm{L}=$ labour in country $j$ and year $t$

$A=$ parameter that measures total factor productivity

$\alpha$ and $1-\alpha$ are the relative shares of capital and labour from the total production.

Taking logarithms on both sides of equation (1), the equation becomes:

$\ln Y_{j t}=C+\alpha \ln K_{j t}+1-\alpha \ln L_{j t}+U_{j t}$ 
Equation (2) was further simplified to become:

$\ln Y_{j t}=a_{0}+a_{1} \ln K_{j t}+a_{2} \ln L_{j t}+U_{j t}$

Where $a_{0}$ is a constant term, $\ln Y_{j t}, \ln K_{j t}$ and $\ln L_{j t}$ are respectively the natural logarithms of $Y_{j t}, K_{j t}$, and $L_{j t} . U_{j t}$ is the error term. $a_{1}$ and $a_{2}$ are elasticity coefficients.

Equation (3) was used in the model section to derive the model to be used to establish the relationship between employment and economic growth in Sub-Saharan Africa.

\subsection{Model: Effect of Economic sectors on employment in Sub-Saharan Africa}

To investigate the effect of economic sectors on employment in Sub-Saharan African countries equation 3 was further modified into an appropriate form by including the contributions of the three sectors of the economy in the equation. The economic sectors were: Agriculture value added, manufacturing value added and services value added. The equation was also used to simultaneously estimate the effect of foreign direct investment and population; rural and urban population on employment as follows:

$\operatorname{lnEmpl}_{j t}=a_{0}+a_{7} \ln K_{j t}+a_{2} \operatorname{lnPopn}_{j t}+a_{3} \ln X_{j t}+a_{4} \ln M_{j t}+a_{5} \ln A g r_{j t}+a_{6} \operatorname{lnMan_{jt}}+a_{7} \operatorname{lnSer} \operatorname{si}_{j t}+a_{8} \operatorname{lnFDI_{jt}}+$

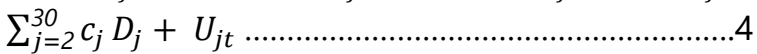

Where Popn, Agr, Man, Ser are total population, agricultural value added, manufacturing value added and services value added respectively, and $\mathrm{a} 0$ to $\mathrm{a}_{8}$ are parameters of estimation

Variables of interest included agriculture value added, service value added, and manufacturing value added which were all used to determine the effect of the economic sectors on employment in the Sub-Saharan African countries. Other variables included total population, urban population, and rural population, and value of imports and exports. Foreign Direct Investment (FDI) was used as well and its data had been obtained from FAOSTAT data base.

\subsection{Estimation Methods}

The panel data was used in the investigation of the effect of economic sectors on employment in Sub-Saharan Africa. A total of 30 countries were included in the study with data spanning the period between 1990 and 2015. Hausman test was used to confirm whether fixed effects specifications were preferred to random effects specifications for the data used in this study. Country dummies were used in the estimations as this took care of country differences as different countries operated in different conditions.

This study employed STATA statistical package in the regression analysis. The coefficients as presented in the model were read directly as elasticity's for all the variables in the model. The sign and significance of the coefficients indicated the direction of the impact by the independent variables on the dependent variable.

\subsection{RESULTS AND DISCUSSION}

\subsubsection{Effect of Economic Sectors on Employment in Sub Saharan Africa over the period 1990 to 2015}

The regression findings of the research question on effect of economic sectors on employment in Sub-Saharan Africa were presented in this section. The study aimed at establishing the contribution of the economic sectors to employment of the entire population, rural population and urban population as well as the contribution of the economic sectors which comprise of imports, exports, agriculture, manufacturing, service sector and foreign direct investment to employment in Sub-Saharan Africa. The results were estimated using the equation with country dummies and the elasticity's of the independent variables are as presented in Table 1. The problem of heteroskedasticity was dealt with by including robust in the stata command during the running of the results using fixed effects with country dummies

The regression results gave an $R^{2}$ that was very high at .954 implying that over 95 percent of employment in SSA is explained by the included independent variables. The estimated results were obtained based on the traditional neo-classical aggregate production function as in the equation 4 . The results were estimated after carrying out a Hausman test. The results that were got from the test indicated that fixed effects were preferred to random effects. The results as presented in table 1 presents elasticity's of total population, imports, exports, 
agriculture, manufacturing, service sector, foreign direct investment, urban population, and rural population with respect to employment in Sub Saharan Africa.

From table 1, the first column captures results for all the variables of interest, so the results for this column are the one that were used in reporting the findings for most of the variables, which comprise of; total population, imports, exports, agriculture, manufacturing, service, and foreign direct investment, while column 2 and 3 captures the regression results for urban population and rural population respectively.

The following findings were obtained from the results in table 1 . First, the elasticity of total population is positive and statistically significant at 0.01 significance level. Its elasticity coefficient is 1.012 as shown in table 1 column one. This is the highest response to employment and it implies that a $1 \%$ increase in total population will result in increase in employment by $1.012 \%$. This is due to the fact that the Sub-Saharan Africa people always look for ways of earning a livelihood, and this is made possible by this people getting engaged in any form of economic activity, which is referred to as employment. This is a positive and significant contribution to employment for the people who live in Sub Saharan Africa. This is in line with the findings of IMF (2012), Filmer et al, (2013) and (Fox et al 2013) IMF (2013) among others.

Second, the findings indicated that imports was found to have a positive and statistically significant coefficient of 0.0164 at 0.1 significance level. This translated to mean that a $10 \%$ increase in imports lead to an increase in employment by about $0.0164 \%$. This was a significant response to employment in Sub-Saharan Africa. This actually is an indication that imports were generating significant jobs in Sub-Saharan Africa in the imports supply chain in the region. This result is congruent with those of Bigsten (2012) and IMF (2013) who found that the SSA countries were importing refined products like petroleum for instance Nigeria that is more expensive than the crude oil that they had exported, and this doesn't generate a lot of revenue needed for job creation, though they benefit from the aspect of comparative advantage and economies of scale. The imports chain as well creates significant number of jobs in the SSA region.

Thirdly the regression results indicated that exports was found to have a negative and significant coefficient of negative 0.0141 at 0.05 significance level. This implied that a $5 \%$ increase in exports will lead to a decrease in employment by about 0.0141 percent. This was not the expected result but again this can be explained by the value of the export commodities from the Sub - Saharan African region, majorly comprising of agricultural products and minerals from extractive industries that have mostly little value addition done on them, thus the export value chain employ a significant number of employees in Sub-Saharan Africa. This result is congruent with the finding of Acet (2014). World Bank (2014) had their finding being in line with the finding of this study as they established that export of commodities such as fuel, minerals and agriculture products in their unprocessed form constituted the biggest share of exports from SSA countries which resulted in generation of lesser revenue that couldn't support generation of adequate jobs for this region.

Fourthly, the agriculture sector has a negative but significant effect on employment as its elasticity coefficient was negative 0.0159 at 0.1 percent significance level. This implied that a $10 \%$ increase in agricultural production will lead to a decrease in employment by about $0.0159 \%$ which is a significant contribution. This is due to the fact that the agricultural sector isn't very attractive to the educated and technologically knowledgeable youthful population who constitute more than 40 percent of the entire population in Sub-Saharan Africa, and this generation of job seekers flock into towns and cities looking for better paying white colour jobs, leaving their parents and grandparents in the country side engaging in mainly subsistence farming. Agriculture is not attractive due to its low productivity levels resulting in low wages (Aggarwal Francis \& Robinson (2018).The cash crops for instance the horticulture and floriculture industry mainly employs majority of low skilled people and the jobs they mostly offer are manual jobs that are taken by mostly women. Global competition and vagaries of weather due to global warming are negatively impacting the agricultural sector thus this countries need to adopt irrigation farming and use of greenhouses and endeavor to pay better wages and provide better working conditions so as to create good jobs. Majority of the agribusinesses in Sub-Saharan Africa are again foreign owned, hence the reason of capital flight and the growth of this industry is as a result affected. The other predicament bedeviling this sector is that most of the agricultural produce is exported raw with minimal value addition done on them thus they do not fetch high prices in the world market, a thing that reduces the revenue needed to develop more employment in this sector. Actually the agricultural sector has been declining for more 
than a decade in SSA. Afrobarometer, (2013) found that there was reduction in the number of people who were employed in the Agricultural sector and more people were being employed in other sectors such as the services sector that were growing rapidly, an explanation that supports the finding of this study. This result is line with finding of Fox et al (2013), Fine et al (2012), World Bank (2014) and Timmer (1988), Szirmai and Verspagen (2015) among others.

The fifth finding indicated that manufacturing was found to have a positive and statistically significant elasticity coefficient of 0.0209 at 0.01 significance level. This meant that a $1 \%$ increase in manufacturing will lead to an increase in employment by about $0.0209 \%$. This was a significant influence on employment which is really encouraging, and it thus indicates that the solution of unemployment in Sub-Saharan Africa lies in setting up more industries so as to create more jobs for the citizens of this region. This result is congruent to the findings of Wonyra (2018), Rodrik (2014), Mc Millan and Harttage (2014), MC Millan and Rodrik (2011), Townsend (2017), Filmer and Fox (2013), and Fox et al (2014) among others.

The sixth finding indicated that the service sector was found to have a positive coefficient of 0.00765 which was not significant. This implied that the services sector was contributing to employment among the SSA countries though its contribution was not significant. Some countries in Sub-Saharan Africa though they have a vibrant services sector, the sector is still in its nascent stage unlike the one in the developed countries that is highly sophisticated and thriving, greately contributing a very big chunk to employment. This is in spite of the fact that this sector has had more than one decade of great growth in this SSA region. This result is in line with the finding of Yeboa \& Jayne (2016) who found the services sector to be a very vibrant sector that was growing and having an increasing capacity of absorbing more employees, and that it was absorbing the employees from the declining Agricultural sector. Accenture (2014) found that there were some SSA countries that had greatly benefited by the contribution of the services sector to employment. Filmer and Fox (2013), Fox et al (2014) and Yeboah and Jayne (2016) had similar results to the findings of this study.

It was found in the seventh finding that foreign direct investment had a negative and insignificant coefficient of negative 0.000515 . This finding is however not significant. This could probably be due to the fact that the foreign direct investment allocated to the Sub-Saharan Africa region is normally allocated majorly to some very few countries, leaving the rest of the countries with a very small share thus it doesn't as much have a significant contribution to employment creation in this region. This could as well be due to the skepticism that some countries in this region view foreign direct investment with, as they think it comes with some conditions. This is as well evidenced by for instance the environmental issues that the Nigerian oil industry had as its environment was degraded (IEA, 2003), but there is evidence that FDI can aid in employment generation as well as economic growth through the recipient country channeling FDI in the secondary sector as was evidenced among the East Asian countries instead of the primary sector as most of African countries do resulting in reduction in employment generation as a result (Moss et al 2004).

The eighth finding indicated that urban population was found to have a positive and statistically significant elasticity coefficient of 0.659 at 0.01 significance level. On average, $1 \%$ increase in urban population will lead to an increase in employment by about $0.659 \%$. This was a significant contribution on employment, and it is due to the fact that most of the industries in Sub - Saharan region are situated in urban centers, and the urban population get employed in them, with some people in the urban areas in Sub-Saharan Africa setting up various forms of ventures which end up employing more people and most of the ventures in the urban setting pay better wages in comparison to the agricultural sector that is located in the rural areas, which attracts or creates rural urban migration. Other sectors such as the service sector are as well majorly situated in urban areas in Sub Saharan Africa and they significantly contribute to employment of the urban population. This result is similar with the finding of Dieterich et al (2016) and Fox and Sohnesen (2012) among others.

Lastly, the finding indicated that rural population was found to have a positive and significant coefficient of 0.633 at 0.01 significance level. On average, $1 \%$ increase in rural population will lead to an increase in employment by about $0.633 \%$. This was a significant contribution to employment in Sub Saharan Africa. This is explained by the fact that there are jobs in rural farms, for farming and for engaging in agribusiness. If this is exploited, the level of unemployment in the Sub-Saharan Africa would diminish. The governments in SubSaharan Africa should make farming attractive so as to entice the huge youthful population to go to rural areas 
to engage in farming by giving subsidies to farmers and setting up more agro based industries in rural areas and reducing taxation on agricultural inputs as well as outputs. This result is in line with the finding of Croppendstedt et al., (2013) Fox and Sohnesen, (2012), and Fox et al. (2013).

\subsection{Table 1 : Effect of Economic Sectors on Employment in SSA over the period 1990-2015}

\begin{tabular}{|c|c|c|c|}
\hline & (1) & (2) & (3) \\
\hline Variables & Inempl & Inempl & Inempl \\
\hline popn_log & $\begin{array}{l}1.012^{\star \star \star} \\
(0.0206)\end{array}$ & & \\
\hline impo_log & $\begin{array}{l}0.0164^{*} \\
(0.00893)\end{array}$ & $\begin{array}{l}0.0381^{* * *} \\
(0.0107)\end{array}$ & $\begin{array}{l}0.101^{* * *} \\
(0.0164)\end{array}$ \\
\hline expo_log & $\begin{array}{l}-0.0141^{* *} \\
(0.00716)\end{array}$ & $\begin{array}{l}-0.0171^{* *} \\
(0.00866)\end{array}$ & $\begin{array}{l}-0.0105 \\
(0.0135)\end{array}$ \\
\hline agri_log & $\begin{array}{l}-0.0159 * \\
(0.00951)\end{array}$ & $\begin{array}{l}-0.0157 \\
(0.0116)\end{array}$ & $\begin{array}{l}0.0425^{* *} \\
(0.0180)\end{array}$ \\
\hline manu_log & $\begin{array}{l}0.0209 * * * \\
(0.00549)\end{array}$ & $\begin{array}{l}-0.0145^{* *} \\
(0.00691)\end{array}$ & $\begin{array}{l}0.0618^{* * *} \\
(0.0102)\end{array}$ \\
\hline serv_log & $\begin{array}{l}0.00765 \\
(0.00567)\end{array}$ & $\begin{array}{l}0.00478 \\
(0.00691)\end{array}$ & $\begin{array}{l}0.0444^{* * *} \\
(0.0106)\end{array}$ \\
\hline fdi_log & $\begin{array}{l}-0.000515 \\
(0.00159)\end{array}$ & $\begin{array}{l}0.00658^{\star \star \star} \\
(0.00188)\end{array}$ & $\begin{array}{l}0.0106^{* * *} \\
(0.00299)\end{array}$ \\
\hline popu_log & & $\begin{array}{l}0.659 * * * \\
(0.0173)\end{array}$ & \\
\hline popr_log & & & $\begin{array}{l}0.633^{* * *} \\
(0.0419)\end{array}$ \\
\hline Constant & $\begin{array}{l}-1.663^{\star \star \star} \\
(0.238)\end{array}$ & $\begin{array}{l}5.206^{* * *} \\
(0.250)\end{array}$ & $\begin{array}{l}-1.094 \text { ** } \\
(0.526)\end{array}$ \\
\hline Country Dummy & Yes & Yes & Yes \\
\hline Observations & 661 & 661 & 661 \\
\hline R-squared & 0.954 & 0.932 & 0.835 \\
\hline Number of ID & 30 & 30 & 30 \\
\hline
\end{tabular}

2. Standard errors in parentheses

3. $\quad * * * p<0.01,{ }^{* *} p<0.05,{ }^{*} p<0.1$

\subsubsection{Summary of the findings}

The study established that total population, imports, manufacturing, urban population and rural population were found to positively and statistically significantly influence employment in Sub Saharan Africa, while exports 
and the Agricultural sector were found to negatively and statistically significantly influence employment in SSA The services sector was found to positively influence employment though not statically significant. On the other hand, foreign direct investment was found to negatively influence employment but it wasn't statistically significant.

\subsection{CONCLUSION AND RECOMMENDATIONS}

\subsubsection{Conclusion and recommendations on effect of economic sectors on employment in SSA}

From the findings of the study, it was concluded that only foreign direct investment negatively influenced employment in SSA though the influence was not statistically significant. The services sector on the other hand positively influenced employment but was not statistically significant.

The export sector and the Agricultural sector variables negatively and statistically significantly influenced employment in SSA. All the other variables, namely total population, imports, manufacturing, urban population and rural population positively and statistically significantly influenced employment in the Sub Saharan African region.

Basing on the above conclusions it is recommended that the Sub Saharan African countries should rethink their export and Agricultural sectors policies and adopt better ones that can generate and support more employment in the Sub Saharan African region, as most of the exports from this region are from the Agricultural sector and most of them are in their raw non processed form, more Agro based industries should be set up so as to process and add value to the Agricultural export from this region. More industries should be set up so as to process and refine the minerals being exported from this region with an intent of adding value on them. The Governments of the SSA region should come up with policies of encouraging adoption and support of technological capabilities so as to invent and innovate more new products with an intent of improving the value of exports from this region. The SSA governments should as well improve on their policies on manufacturing and services sectors so as to grow this sectors and by so doing create more job opportunities in this region

\section{REFERENCES}

[1]Adams, S. (2008), Foreign direct investment, domestic saving and economic growth in Sub-Saharan Africa, Journal of Policy Modeling, doi:10.1016/j.jpolmod.2009.03.003

[2]African Center for Economic Transformation (2014). Growth with Depth: The 2014 African Transformational Report. ACET Accra, Ghana.

[3] AfDB, WB etc., (2009). Africa's Infrastructure a Time for Transformation,

[4] Aggarwal, S., Francis, E., \& Robinson, J. (2018). Grain today, gain tomorrow: evidence from a storage experiment with savings clubs in Kenya. Journal of Development Economics, 134(March), 1-15.

[5]African Development Report (2015). Growth, poverty and inequality nexus: Overcoming barrier to sustainable development. Abidjan: African Development Bank.

[6] AfDB, OECD, UNDP, UNECA, (2013). Structural Transformation and Natural Resources, African Economic Outlook.

[7] Afrobarometer, (2013). Data available at www. Afrobarometer.org.

[8] Aggarwal, S., Francis, E., \& Robinson, J. (2018). Grain today, gain tomorrow: evidence from a storage experiment with savings clubs in Kenya. Journal of Development Economics,

[9] Baltzer. K Hansen. H. (2011).134(March), 1-15. Agricultural input subsidies in Sub-Saharan Africa, Institute of Food and Resource Economics, University of Copenhagen Published by: Ministry of Foreign Affairs of Denmark Evaluation Department.

[10] Bayraktar, N., \& Fofack, H. (2018). A model for gender analysis with informal productive and financial sectors. Journal of African Development, 20(2), 1-20. 
[11] Bhandari, R., Dhakal D., Pradhan G., Upadhyaya K. (2007). "Foreign aid, FDI and economic growth in East European countries". Economics Bulletin, vol. 6, no 13 pp. 1-9

[12] Bigsten, A, (2012). Comparative Advantage and African Development, The Oxford companion to the economics of Africa, 2012, p. 169.

[13] Croppenstedt, A., Goldstein, M., \& Rosas, N. (2013). Gender and agriculture: Inefficiencies,

Segregation, and low productivity traps. The World Bank Research Observer, Iks024.

[14] Deressa, T.T, and Mbaku, J.M July (2013). While Egypt Struggles, Ethiopia Builds over the Blue Nile: Controversies and the Way Forward, The Africa Infrastructure Development Index (Aidi), AfDB, May 2013.

[15] Dieterich, C.; Hakura, D. and Newiak, M. (2016), 'In the Driver's Seat', Finance \& Development, June 2016, 22 $-24$.

[16] Dasgupta, S. and A. Singh, 2005. Will services be the new engine of Indian economic growth? Development and Change, 36(6): 1035-1057. Available at: https://doi.org/10.1111/j.0012-155x.2005.00449x.

[17] EIA (2003). Nigeria: Environmental issues. Country Analysis Briefs, Energy Information Administration, US Department of Energy, July.

[18] Elu, J. (2018). Gender and science education in sub-Saharan Africa- Keynote address at the African Development Bank/African Finance and Economic Association Luncheon, Chicago, January 7, 2017. Journal of African Development, 20(2), 105-110.

[19]EY, (2013). Africa Attractiveness Survey 2013.

[20]EY (2014). Africa attractiveness survey March (2014)

[21]FAO (2011). The state of food and agriculture: Women in agriculture-closing the gender gap for development. Rome: Food and Agriculture Organization.

[22] Fei, J.C.H. and G. Ranis, (1964). Development of the labour surplus economy. Theory and policy. Homewood, IL: Irwin.

[23] Filmer, Deon, Fox, Louise, and others, (2013). Africa Regional Report on Youth Employment, Washington: The World Bank.

[24] Filmer, D., \& Fox, L. (2014). Youth employment in sub-Saharan Africa. Washington: The World Bank publication.

[25]Fine D., van Wamelen A., Lund S., Cabral A., Taoufiki M., Dörr N., Leke A., Roxburgh C.,

Schubert J., Cook P. (2012) Africa at Work: Job Creation and Inclusive Growth. Washington, D.C.: McKinsey Global Institute.

[26] Financial Times, 21 October (2015).Chinese investment in Africa plunges 84\%.

[27]Wallis. W. (2015). Ghana Reaches \$1bn Deal with IMF, Financial Times, February 2015.

[28]Fox, L., Haines, C., Muñoz, J. H., \& Thomas, A. H. (2013). Africa's got work to do: employment prospects in the new century. IMF Working Papers (Vol. 13). Retrieved from: https://www.imf.org/external/pubs/ft/wp/2013/wp13201.pdf

[29]IFPRI (2014). Gender in agriculture: Closing the knowledge gap. Washington, D.C: International Food Policy Research Institute

[30]IMF (2012). Coping with High Debt and Sluggish Growth. World Economic Outlook October 2012 International Monetary Fund. New York.-Washington, D.C.:

[31]IMF African Department, (2013). Boom, Bust, or Prosperity? Managing Sub-Saharan Africa's Natural Resource Wealth, International Monetary Fund. New York.-Washington, D.C.: 
[32] Inklaar, R., M.P. Timmer and B. Van Ark, (2008). Market services productivity across Europe and the US. Economic Policy, 23(53): 140-194. Available at: https://doi.org/10.1111/j.1468 0327.2007.00194.x.

[33] Kaldor, N., (1966). Causes of the slow rate of growth of the United Kingdom. Cambridge: Cambridge University Press.

[34] Khawar, M. (2005). Foreign direct investment and economic growth: a cross-country analysis. Global Economy Journal, 5(1): 1-13

[35]Kelley, Allen C., and Robert M. Schmidt. 1995. "Saving, Dependency, and Development." Journal of Population Economics 9(4): 365-86.

[36]Li, X., Liu, X. (2005). Foreign direct investment and economic growth: an increasingly endogenous relationship. World Development, vol. 33, pp. 393-407.

[37]Lin, J. Y. (2012), Structural Change in Africa, The Oxford companion to the economics of Africa, p. 297.

[38] Mannah-Blankson, T. (2018). Gender inequality and access to microfinance: Evidence from Ghana. Journal of African Development, 20(2), 21-33.

[39] Manyire, H., \& Apekey, A. D. (2013). Mainstreaming gender equality in African agricultural research and development: A study of constraints and opportunities. Accra: Forum for Agricultural Research in Africa (FARA).

[40]McKinsey \& Co., June (2010). Lions on the Move: The Progress and Potential of African Economies, Westminster London, January.

[41]McMillan, M. S., \& Rodrik, D. (2011). Globalization, structural change and productivity growth (NBER Working Paper Series No. 17143). Cambridge, MA: NBER. Retrieved from http://www.nber.org/papers/w17143.

[42]McMillan, M., Rodrik, D., \& Verduzco, Í. (2014). Globalization, structural change and productivity growth, with an update on Africa. World Development, 63, 11-32.

[43]McMillan, M. and Harttgen,K. (2014). What is Driving the 'African Growth Miracle'?

African Development Bank Group, Working Paper Series no 209, October 2014.

[44]Moss, T. Ramachandran, V., \& Shah, M. (2004). Is Africa's skepticism of foreign capital justified? Evidence from East African firm survey data. Center for Global Development, Working Paper No. 41.

[45] Ndambendia, H. and Njoupouognigni. M. (2010). Foreign Aid, Foreign Direct Investment and Economic Growth in Sub-Saharan Africa: Evidence from Pooled Mean Group Estimator (PMG). International Journal of Economics and Finance Vol. 2, No. 3 Published by Canadian Center of Science and Education

[46] Neslen, A. (2015). Morocco poised to become a solar superpower with launch of desert mega-project, The Guardian, October 2015.

[47]Page, J. (2012). Industry for Africa. Why? How? The Oxford companion to the economics of Africa, 2012, p. 307. Offord University press, UK.

[48] Rodrik, D., (2009). Growth after the crisis. Cambridge, MA: Harvard Kennedy School.

[49] Rodrik, D. (2014). An African growth miracle? Institute for Advanced Study, Princeton, April 2014.

[50]Socrates. K. M. (2020). The Effect of Lockdown Policies on International Trade Flows from Developing Countries: Event Study Evidence from Kenya University of Nairobi, Kenya.

[51] Szirmai, A., (2012). Industrialisation as an engine of growth in developing countries, 1950-2005. Structural Change and Economic Dynamics, 23(4): 406-420. Available at: https://doi.org/10.1016/j.strueco.2011.01.005.

[52] Szirmai, A. and B. Verspagen, (2015). Manufacturing and economic growth in developing countries, 19502005. Structural Change and Economic Dynamics, 34: 46-59. Available at: https://doi.org/10.1016/j.strueco.2015.06.002. 
[53]The Economist, March (2014). Employment in Sub-Saharan Africa. Sorry, no vacancies, Pearson publishers London

[54]The Economist, February (2015). African roads and rails. All aboard. Pearson publishers, London.

[55] Timmer, C. Peter, (1988) "The Agricultural Transformation." In H. Chenery and T.N.Srinivasan,eds., Vol. 1, pp. 276-331 (Amsterdam: Elsevier). Handbook of Development Economics.

[56] Timmer, M.P. and G.J. De Vries, (2009). Structural change and growth accelerations in Asia and Latin America: A new sectoral data set. Cliometrica, 3(2): 165-190. Available at: https://doi.org/10.1007/s11698-0080029-5.

[57] Townsend, R., Benfica, R., Prasann, A., \& Lee, M. (2017). Future of food: shaping the food system to deliver jobs. World Bank Group. Retrieved https://openknowledge.worldbank.org/bitstream/handle/10986/26506/114394-WP-PUBLIC-18-4-2017-10-5645 ShapingtheFoodSystemtoDeliverJobs.pdf? sequence $=1$ \&isAllowed $=y$

[58] Uduji, J. I., \& Okolo-Obasi, E. N. (2018a). Adoption of improved crop varieties by involving farmers in the ewallet programme in Nigeria. Journal of Crop Improvement https://doi.org/10.1080/15427528.1496216, 32, 717 737.

[59] Uduji, J. I., Okolo-Obasi, E. N. and Asongu S. A (2019). Corporate social responsibility and the role of rural women in sustainable agricultural development in Sub-Saharan Africa: evidence from the Niger Delta in Nigeria. Journal of Sustainable Development. 2019; 1-12. John Wiley \& Sons, Ltd and ERP Environment

[60]UNECA \& AU, (2014), Dynamic industrial policy in Africa (2014). Economic Report on Africa, Action Plan for the Accelerated Industrial Development of Africa, African Union Department of Trade and Industry.

[61]Vazirani, M. Mthethwa, D. Pane, L Pichler,A Hintermann, F Naidoo,A and Lack D. (2014) Ideal Model for Financial Services in Africa. At the Tipping Point: an inclusive approach, Accenture, 2014, p. 6.

[62]World Bank, October (2014). Africa's Pulse, Washington, DC: The World Bank Group.

[63]Wonyra, O. K. (2018). Industrialization and Economic Growth in Sub-Saharan Africa: The Role of Human Capital in Structural Transformation. Journal of Empirical Studies Vol. 5, No. 1, pp. 45-54 ISSN (e): 2312-6248

[64] Xu, G., Wang, R. (2007). The effects of foreign direct investment on domestic capital formation, trade and economic growth in transition economies: evidence from China. Global Economy Journal, 7(2): 1-21.

[65] Yeboah, F. K., \& Jayne, T. S. (2016). Africa's evolving employment structure: causes and consequences. Retrieved from: http://www.fao.org/3/a-bp111e.pdf

[66] Zamfir, I. (2016). Africa's economic growth taking off or slowing down? Members research service DirectorateGeneral for parliamentary research services, European Union Parliament 